\title{
A Novel Missense Mutation (P366T) of the LHX4 Gene Causes Severe Combined Pituitary Hormone Deficiency with Pituitary Hypoplasia, Ectopic Posterior Lobe and a Poorly Developed Sella Turcica
}

\author{
TOSHIHIRo TAJIMA, TSUKASA HATTORI*, TAKEO NAKAJIMA*, KOJI OKUHARA, JUNKO TSUBAKI \\ AND KENJI FUJIEDA** \\ Department of Pediatrics, Hokkaido University School of Medicine, N15, W7, Sapporo 060-0835, Japan \\ *Department of Neonatology, Sapporo City Hospital, N14, W12, Sapporo, Japan \\ **Department of Pediatrics, Asahikawa Medical College 2-1-1-1, Midorigaoka, Higashi, Asahikawa 078-8510, Japan
}

\begin{abstract}
LIM homeodomain transcription factors regulate many aspects of development in multicellular organisms. LHX4/Lhx4 is a protein that is essential for pituitary development and motor neuron specification in mammals. In human, a heterozygous splicing mutation of the LHX4 gene was reported in a family with combined pituitary hormone deficiencies (CPHD). In addition to CPHD, these patients were characterized by small sella turcica and chiari malformation. Here we report a Japanese patient with CPHD (GH, PRL, TSH, LH, FSH, and ACTH deficiency) due to a novel missense mutation (P366T) of the LHX 4 gene. She showed severe respiratory disease and hypoglycemia soon after birth. Brain MRI demonstrated hypoplastic anterior pituitary, ectopic posterior lobe, a poorly developed sella turcica, and chiari malformation. Sequence analysis of the LHX 4 gene identified a heterozygous missense mutation (P366T) in exon 6, which was present in LIM4 specific domain. Neither of the patient's parents harbored this mutation, indicating de novo mutation.
\end{abstract}

Key words: LHX4, Combined pituitary hormone deficiency (CPHD), Pituitary hypoplasia, Sella turcica

(Endocrine Journal 54: 637-641, 2007)

GENETIC defects affecting the hypothalamic-pituitarytarget organ axes can cause a variety of diseases involving restricted or broad disruptions of human development and physiology. Within the hypothalamicpituitary target organs, there are three main levels at which genetic defects can occur that cause diseases: the level of hypothalamus, the level of the pituitary gland, and the level of the pituitary target organs $[1,2]$. The anterior pituitary gland develops from a midline structure contiguous with the primordium of the ventral diencephalons [3, 4]. After proliferation from a

Received: November 21, 2006

Accepted: February 28, 2007

Correspondence to: Toshihiro TAJIMA, M.D., Ph.D., Department of Pediatrics, Hokkaido University School of Medicine, N15, W7, Sapporo 060-0835, Japan well-defined growth plate, different cell types arise in a distinct spatial and temporal fashion and undergo a highly selective determination and differentiation [3, 4]. Thereafter, numerous cells in the pituitary gland are specialized to produce and secrete specific hormones, such as GH, PRL, TSH, LH, FSH, and ACTH. These processes are controlled by the actions of pituitary-specific and pituitary-enriched transcription factors $[1,2]$. These factors include POUF1/Pit1, PROP1/Prop1, SF-1/Sf-1, PITX2/Pitx2, NeuroD1, GATA-2, LHX3/Lhx3, TPIT/Tpit, LHX4/Lhx4, and HESX1/Hesx1 [5-15]. Recent investigations in mice and human have clarified that mutations in genes encoding several of these factors can lead to both structural defects of pituitary gland and to deficiencies of anterior pituitary hormones [combined pituitary hormone deficiency (CPHD)] [5-15]. 
LHX3/Lhx3 and LHX4/Lhx4 are the LIM homeodomain protein family and are characterized by two LIM domains and a homeodomain [12, 14, 16]. In general LIM homeodomain genes are widely expressed throughout development in complex and often overlapping patterns, implicating these genes in a variety of regulatory events $[12,14,16]$. Lhx 4 of mouse is expressed in the developing neural tube, hindbrain, Rathke's pouch, and pituitary gland [16-18]. Disruption of the mouse Lhx4 gene has demonstrated the defect of proliferation of all anterior pituitary cell lineages and abnormal differentiation of corticotroph, resulting in anterior pituitary hypoplasia $[17,18]$. In human, so far only one mutation of the LHX4 gene in a family has been reported to cause CPHD [14].

Here we report a Japanese patient of severe CPHD with a poorly developed sella turcica. In this patient a novel heterozygous missense mutation of the LHX4 gene was identified.

\section{Case Report}

The patient is now a 16-month old Japanese girl. She was born after 38 weeks of gestation by cesarean section due to breech position. She was the second child of nonconsanguineous parents. Her birth weight was $2216 \mathrm{~g}$ ( $-2.0 \mathrm{SD}$ for a Japanese girl) and length was $40.5 \mathrm{~cm}$ ( $-2.2 \mathrm{SD}$ for a Japanese girl). Soon after birth she showed tachypnea and cyanosis. At this time she was found to be hypoglycemic $(8 \mathrm{mg} / \mathrm{dl})$. Despite oxygen therapy, her respiratory distress deteriorated within 16 hours after birth and the presumed diagnosis of respiratory distress syndrome (RDS) was made. Therefore, mechanical ventilation was started and surfactant was given. Mechanical ventilation was required for 7 days. Neonatal mass screening for congenital hypothyroidism at 10 days of age demonstrated markedly low free T4 and non-elevated TSH levels (free T4 $0.2 \mathrm{ng} / \mathrm{dl}$, TSH, $0.17 \mu \mathrm{U} / \mathrm{mL}$ ). Despite improvement of her respiratory condition, she showed failure to thrive. Re-examination of thyroid function in serum at 17 days of age showed very low levels of free T4 and T3 (free T4, $0.21 \mathrm{ng} / \mathrm{dl}$, free T3 $0.45 \mathrm{pg} /$ $\mathrm{ml}$, and TSH $<0.05 \mu \mathrm{U} / \mathrm{mL}$ ) (Table 1). Central hypothyroidism was evident and thyroid hormone replacement was commenced. At this time, plasma ACTH and serum cortisol levels were also found to be very low $(5.6 \mathrm{pg} / \mathrm{ml}$ and $1.0 \mu \mathrm{g} / \mathrm{dl}$, respectively) (Table 1).
Table 1. Endocrinological findings

\begin{tabular}{ll}
\hline free T4 $(\mathrm{ng} / \mathrm{dl})$ & 0.21 \\
free T3 $(\mathrm{pg} / \mathrm{ml})$ & 0.45 \\
TSH $(\mu \mathrm{U} / \mathrm{mL})$ & $<0.05$ \\
PRL $(\mathrm{ng} / \mathrm{ml})^{\#}$ & $<2$ \\
IGF-1 $(\mathrm{ng} / \mathrm{ml})$ & 5.53 \\
Arginine test & \\
$\quad$ GH $(\mathrm{ng} / \mathrm{ml})$ & $0.16 \rightarrow 0.18$ \\
GHRH test & \\
GH $(\mathrm{ng} / \mathrm{ml})$ & $0.20 \rightarrow 0.21$ \\
Gn-RH stimulation & \\
LH $(\mathrm{mIU} / \mathrm{mL})^{\#}$ & $0.013 \rightarrow 0.015$ \\
FSH $(\mathrm{mIU} / \mathrm{mL})^{\#}$ & $0.023 \rightarrow 0.033$ \\
ACTH $(\mathrm{pg} / \mathrm{ml})$ & 5.6 \\
Cortisol $(\mu \mathrm{g} / \mathrm{dl})$ & 1.0 \\
\hline
\end{tabular}

These values were determined at 14 days of age.

\# These tests were done at 3 months of age.

Second measurement of serum cortisol and plasma ACTH concentrations remained markedly low. Hydrocortisone $(5 \mathrm{mg} /$ day $)$ was initiated to avoid the consequences of adrenal insufficiency. Episodes of severe hypoglycemia, central hypothyroidism, and adrenal insufficiency strongly suggested the existence of congenital hypopituitarism. Brain magnetic resonance imaging (MRI) showed a very small pituitary gland. At 3 months of age further endocrine evaluation was done. Arginine and GHRH stimulation tests did not increase serum GH levels at all (Table 1). PRL level was also lower than detectable limit. There was no response of LH and FSH levels after GnRH stimulation (Table 1). GH replacement therapy was started at this stage. Re-examination of brain MRI at age 15 months demonstrated hypoplastic pituitary, ectopic posterior lobe, a poorly developed sella turcica and chiari malformation (Fig. 1). Now, her body weight is $6500 \mathrm{~g}$ ( $-3.6 \mathrm{SD}$ for a normal Japanese girl) and height is $63 \mathrm{~cm}$ (-5.6 SD for a normal Japanese girl).

Informed consent to participate in the study was obtained from her parents. This study was approved by the ethical committee of the Hokkaido University School of Medicine. Each exon of the LHX4 gene was amplified by polymerase-chain-reaction (PCR) using primers according to a previous report [14]. Sequence analysis of the LHX4 gene demonstrated a heterozygous one base substitution in exon 6 ( $\mathrm{C}$ to A) (Fig. 2A). This substitution changed proline to theronine at residue 366 in the C-terminus of LHX4 (Fig. 2B). Eighty normal Japanese subjects did not have this base 
(A)

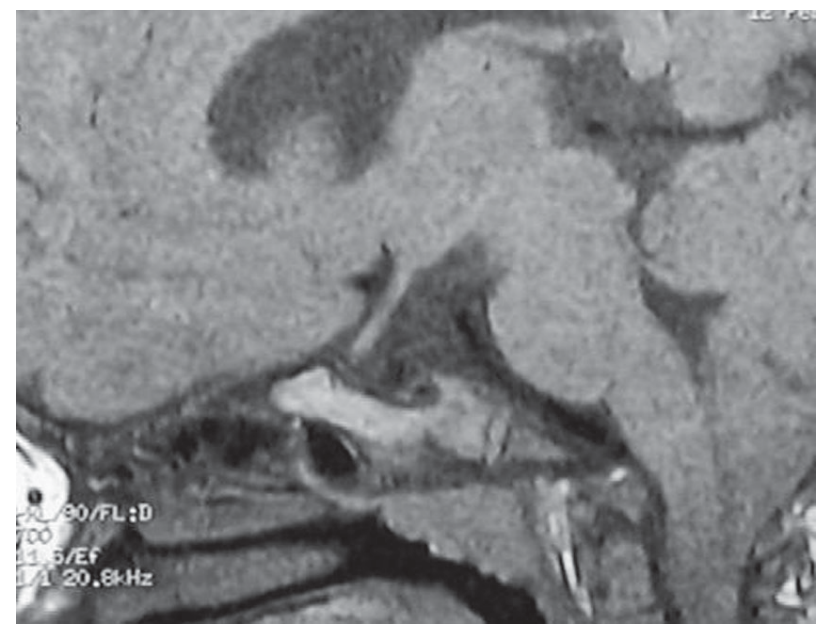

(B)

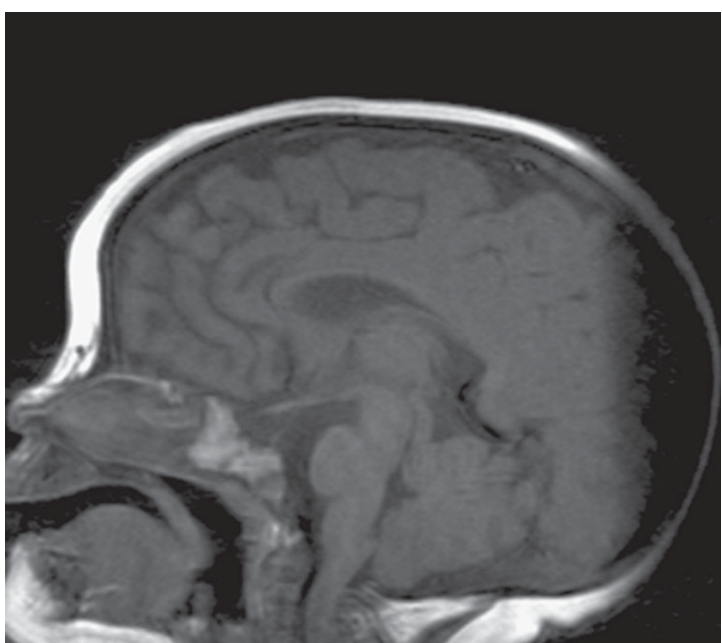

Fig. 1. (A) Sagittal image showed a hypoplastic anterior pituitary and ectopic posterior lobe, and a small sella turcica. (B) Chiari malformation is denoted by an arrow.

Patient

AAXT GG CAT CCTNCT TIT TAAACI T 30
140
P366T

(A)

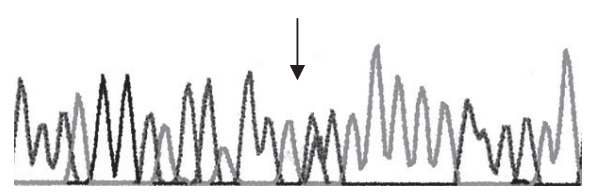

Wild-type

AAA GGAT CAT CCI CCT TTT AAAC 140

P366

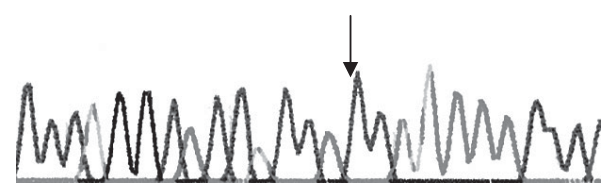

(B)

N-terminus
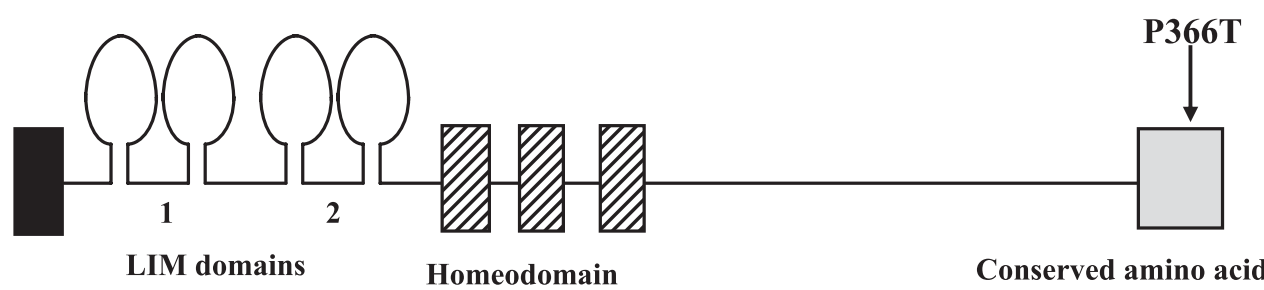

$367 a a$

C-terminus

Conserved amino acid of

C-terminus

Fig. 2. (A) Sequence analysis demonstrated a $\mathrm{C}$ to A transition. This change substitutes threonine for proline at residue 366 . (B) Schematic representation of the LHX4 and the location of P366T. Two LIM domains N-terminus to a homeodomain and the LHX3 and LHX4 specific C-terminal 35 amino acids characterize LHX4.

change. Family analysis demonstrated that neither of her parents harbored this substitution, indicating that the mutation had occurred de novo.

\section{Discussion}

We have reported a Japanese patient of severe CPHD with hyoplastic pituitary, ectopic posterior lobe, small sella turcica and chiari malformation. In the literature, homozygous Lhx4 knockout mice can form Rathke's pouch with expression of all five cell lineages, although the numbers of these cells gradually decreased, resulting in hypoplastic anterior pituitary [17]. Raetzman et al. [18] have reported that this phenomenon is caused by increased apoptosis of cells. This indicates that Lhx4 is essential for the survival of all five cell lineages in the pituitary. These observations of mice are 
concordant with defects of GH, PRL, TSH, LH, FSH and $\mathrm{ACTH}$ in our patient. By contrast, a previous study of one family having a mutation of the LHX4 gene has demonstrated less severe phenotype than our case. Affected members have CPHD with deficiencies in GH, TSH and ACTH. Gonadotropin and PRL levels have not been reported; however, one patient was fertile [14]. One possible explanation of this difference is the penetrance. It is well known that genetic defects of transcription factors do not always show the same pattern of deficient hormones and clinical severity $[1,2,15]$. The other explanation for the difference may be associated with the genotype of the LHX4 mutation. A previous mutation was a heterozygous splice-acceptor site in intron 4 [14]. In vitro expression study revealed that this splicing mutation produced two fragments by using two cryptic spliceacceptor-sites [19]. One protein lacked the helix II and IV of the homeodomain and the other was truncated by a premature stop codon in exon 5. It is possible that these truncated proteins may compensate for normal LHX4 function to some extent.

Our mutation (P366T) was located in the C-terminus of LHX4. The exact functional of the C-terminus of LHX3 and LHX4 has been unknown; however, the 35-amino acid region at the C-terminus of LHX3 and LHX4 is well conserved and shows no significant similarity to other proteins $[12,16,20]$. This fact suggests that this region may have some specific role in LHX3 and LHX4. Further study of the functional consequence of our mutation (P366T) must be done.

MRI analyses of affected members in a previous literature have shown hypoplasia of the pituitary, small sella turcica, and chiari malformation [14]. Our pa- tient also showed severe hypoplasia of the pituitary and small sella turcica, and chiari malformation. Since a poorly developed sella turcica has been also identified in our patient, this abnormality may constitute the phenotypic feature that distinguishes CPHD patients with defects of the LHX4 gene from those reported with mutations in other genes.

Finally, her lung disease is of note. Despite term delivery, she showed respiratory failure resembling neonatal respiratory distress syndrome and required surfactant replacement and mechanical ventilation. $\mathrm{Li}$ et al. [21] reported that early postnatal death in Lhx 4 gene knockout mice was caused by immature lung, which was similar to RDS in human. In that report the exact reason for immature lung was not mentioned. Scommegna et al. [22] described 5 patients with pituitary aplasia identified by MRI scan. In addition to symptoms of hypopituitarism, they showed respiratory distress on the first day of life, in spite of uneventful pregnancy, labor, and delivery. Furthermore, Sobrier et al. [23] described two patients with an anterior pituitary aplasia caused by mutations of the HESX1 gene. They also presented with respiratory distress complicated by shock at birth. As fetal glucocorticoid is well known to be required for lung maturation during fetal life, cortisol deficiency due to ACTH defect may be partly related to lung disease in neonates of severe pituitary hypoplaisa. However, severe congenital isolated ACTH deficiency did not usually show respiratory distress [24]. Considering these facts, other unknown factors might contribute to respiratory distress in patients with severe congenital hypopituitarism. This must be studied further.

\section{References}

1. Cushman LJ, Showalter AD, Rhodes SJ (2002) Genetic defects in the development and function of the anterior pituitary gland. Ann Med 34: 179-191.

2. Amselem S (2002) Current approaches for deciphering the molecular basis of combined anterior pituitary hormone deficiency in humans. Mol Cell Endocrinol 197: 47-56.

3. Ikeda H, Suzuki J, Sasano N, Niizuma H (1988) The development of and morphogenesis of the human pituitary gland. Anat Embryol 178: 327-336.

4. Sheng HZ, Westphal H (1999) Early steps in pituitary organogenesis. Trends Genet 15: 236-240.
5. Pfaffle RW, DiMattia GE, Parks JS, Brown MR, Wit JM, Jansen M, Van der Nat H, Van den Brande JL, Rosenfeld MG, Ingraham HA (1992) Mutation of the POU-specific domain of Pit-1 and hypopituitarism without pituitary hypoplasia. Science 257: 1118-1121.

6. Wu W, Cogan JD, Pfaffle RW, Dasen JS, Frisch H, O’Connell SM, Flynn SE, Brown MR, Mullis PE, Parks JS, Phillips JA 3rd, Rosenfeld MG (1998) Mutations in PROP1 cause familial combined pituitary hormone deficiency. Nat Genet 18: 147-149.

7. Ingraham HA, Lala DS, Ikeda Y, Luo X, Shen WH, Nachtigal MW, Abbud R, Nilson JH, Parker KL (1994) 
The nuclear receptor steroidogenic factor 1 acts at multiple levels of the reproductive axis. Genes Dev 8: 2302-2312.

8. Semina EV, Reiter R, Leysens NJ, Alward WL, Small KW, Datson NA, Siegel-Bartelt J, Bierke-Nelson D, Bitoun P, Zabel BU, Carey JC, Murray JC (1996) Cloning and characterization of a novel bicoid-related homeobox transcription factor gene, RIEG, involved in Rieger syndrome. Nat Genet 14: 392-399.

9. Hermesz E, Mackem S, Mahon KA (1996) Rpx: a novel anterior-restricted homeobox gene progressively activated in the prechordal plate, anterior neural plate and Rathke's pouch of the mouse embryo. Development 122: 41-52.

10. Lamonerie T, Tremblay JJ, Lanctot C, Therrien M, Gauthier Y, Drouin J (1996) PTX1, a bicoid-related homeobox transcription factor involved in transcription of pro-opiomelanocortin (POMC) gene. Genes Dev 10: 1284-1295.

11. Dattani MT, Martinez-Barbera JP, Thomas PQ, Brickman JM, Gupta R, Martensson IL, Toresson H, Fox M, Wales JK, Hindmarsh PC, Krauss S, Beddington RS, Robinson IC (1998) Mutations in the homeobox genes HESX1/Hesx 1 associated with septo-optic dysplasia in human and mouse. Nat Genet 19: 125-133.

12. Netchine I, Sobrier ML, Krude H, Schnabel D, Maghnie M, Marcos E, Duriez B, Cacheux V, Moers A, Goossens M, Gruters A, Amselem S (2000) Mutations in $L H X 3$ result in a new syndrome revealed by combined pituitary hormone deficiency. Nat Genet 5: 182-186.

13. Lamolet B, Pulichino AM, Lamonerie T, Gauthier Y, Brue T, Enjalbert A, Drouin J (2001) A pituitary cellrestricted $\mathrm{T}$ box factor, Tpit, activates POMC transcription in cooperation with Pitx homeoproteins. Cell 104: 849-859.

14. Machinis K, Pantel J, Netchine I, Leger J, Camand OJ, Sobrier ML, Dastot-Le Moal F, Duquesnoy P, Abitbol M, Czernichow P, Amselem S (2001) Syndromic short stature in patients with a germline mutation in the LIM homeobox LHX4. Am J Hum Genet 69: 961-968.

15. Reynaud R, Gueydan M, Saveanu A, Vallette-Kasic S, Enjalbert A, Brue T, Barlier A (2006) Genetic screening of combined pituitary hormone deficiency: experience in 195 patients. J Clin Endocrinol Metab 91: 3329-3336.
16. Thor S, Andersson SG, Tomlinson A, Thomas JB (1999) A LIM-homeodomain combinatorial code for motor-neuron pathway selection. Nature 397: 76-80.

17. Sheng HZ, Moriyama K, Yamashita T, Li H, Karavanov A, Potter S, Mahon KA, Westphal H (1997) Multistep control of pituitary organogenesis. Science 278: 1809-1812.

18. Raetzman LT, Ward R, Camper SA (2002) Lhx4 and Propl are required for cell survival and expansion of the pituitary primordial. Development 129: 4229-4239.

19. Machinis K, Amselem S (2005) Functional relationship between LHX4 and POU1F1 in light of the LHX4 mutation identified in patients with pituitary defects. $J$ Clin Endocrinol Metab 90: 5456-5452.

20. Yamashita T, Moriyama K, Sheng HZ, Westphal H (1997) Lhx4, a LIM homeobox gene. Genomics 44: 144-146.

21. Li H, Witte DP, Branford WW, Aronow BJ, Weinstein M, Kaur S, Wert S, Singh G, Schreiner CM, Whitsett JA (1994) Gsh-4 encodes a LIM-type homeodomain, is expressed in the developing central nervous system and is required for early postnatal survival. EMBO $J 13$ : 2876-2885.

22. Scommegna S, Galeazzi D, Picone S, Farinelli E, Agostino R, Bozzao A, Boscherini B, Cianfarani S (2004) Neonatal identification of pituitary aplasia: a life-saving diagnosis. Review of five cases. Horm Res 62: 10-16.

23. Sobrier ML, Maghnie M, Vie-Luton MP, Secco A, di Iorgi N, Lorini R, Amselem S (2006) Novel HESX1 mutations associated with a life-threatening neonatal phenotype, pituitary aplasia, but normally located posterior pituitary and no optic nerve abnormalities. $J$ Clin Endocrinol Metab 91: 4528-4536.

24. Vallette-Kasic S, Brue T, Pulichino AM, Gueydan M, Barlier A, David M, Nicolino M, Malpuech G, Dechelotte P, Deal C, Van Vliet G, De Vroede M, Riepe FG, Partsch CJ, Sippell WG, Berberoglu M, Atasay B, de Zegher F, Beckers D, Kyllo J, Donohoue P, Fassnacht M, Hahner S, Allolio B, Noordam C, Dunkel L, Hero M, Pigeon B, Weill J, Yigit S, Brauner R, Heinrich JJ, Cummings E, Riddell C, Enjalbert A, Drouin J (2005) Congenital isolated adrenocorticotropin deficiency: an underestimated cause of neonatal death, explained by TPIT gene mutations. J Clin Endocrinol Metab 90: 1323-1331. 